\title{
Ceticismo E VERdAde. EnSAio SObRE A UNIVERSALIDADE RADICAL DE UM PENSAMENTO PÓS-CÉTICO
}

\author{
Abah Andrade ${ }^{1}$
}

Resumo: A partir de um estudo sobre os tropos de Enesidemo consignados e discutidos por Sexto Empírico, em suas Hipotiposis pirrônicas, propomos um ensaio de filosofia no qual a leitura desses tropos nos conduz à necessidade de postular (para o pensamento contemporâneo) uma universalidade nova, radical e intransponível. Por meio dela, não só o teor e o alcance filosóficos do ceticismo podem ser enfatizados (no sentido de um encontro - finalmente - com a táo procurada verdade como aquilo que não pode ser possuído, ou cuja posse anunciada é sempre a revelação de uma unilateralidade), mas também se pode assegurar um lugar de pensamento não-relativista contra a intolerância dogmática ou contra a insatisfaçáo com os conflitos da filosofia.

Palavras-Chave: Epoché. Psique. Physis. Póiesis. Ceticismo. Verdade. Universalidade Radical.

Zombar da filosofia é, em verdade, filosofar [...] nós não acreditamos que toda a filosofia valha uma hora de aflição [...]. O pirronismo é a verdade.

(Pascal)

O discípulo de Pyrro, Timon, diz que quem quer que esteja a fim de levar uma vida feliz deve tomar nota das três seguintes coisas: primeiro, quais objetos são como por natureza; segundo, qual deve ser nossa atitude em relação a eles; e finalmente, o que resultará para aqueles que tomam esta atitude. Agora ele diz que

${ }^{1}$ Professor titular do Departamento de Filosofia da Universidade Federal da Paraíba (UFPB), João Pessoa, PB - Brasil. E-mail: andradesimples@gmail.com

Doutor em Filosofia pela USP. Autor, dentre outros, de Si mesmo como história (Loyola, 2014). (Este artigo é parte do resultado de seu estágio pós-doutoral na UFSC, supervisionado pelo prof. Dr. Jaimir Conte, a quem o autor agradece a gentil acolhida.)

http://dx.doi.org/10.1590/0101-3173.2018.v41n3.02.p9 
Pyrro mostra que os objetos são igualmente indiferentes e incertos e indeterminados porque ou nossos sentidos ou nosso juízos são verdadeiros ou falsos; assim, por esta razão nós não podemos confiar neles mas devemos ser sem julgamento e sem inclinação e impassíveis, dizendo sobre cada coisa que ela não mais é que não é ou ambas são e não são ou nenhuma é e náo é. E Timon diz que para aqueles que tomam esta atitude o resultado será, primeiro, a não-asserção; depois, a tranquilidade.

(Aristócles, in: Eusébio, Preparação para o Evangelho XIV)

Viver não é necessário.

O que é necessário é criar.

(Fernando Pessoa)

A

A ideia central deste trabalho é fazer uma leitura dos tropos de Enesidemo tais como apresentados por Sexto Empírico, em suas Hipotiposis pirrônicas, levando muito a sério a metáfora implícita na ideia de epoché (suspensão do juízo). Quando se "suspende" um juízo, o silêncio entra em cena. Ter-se-á algo a fazer com o silêncio vicejante por baixo do juízo uma vez suspenso? Por meio do explicitar-se daquilo imerso em cada um dos desencontros diante dos quais se tem de exercer a suspensão do juízo (epoché), daquilo para o qual o silêncio aponta, precisamos desbravar uma série de aparências duplas para podermos antever, entre essas aparências, o ponto anterior a elas. Esse ponto anterior será tomado como uma realidade efetiva (hipokeimenon), e efetiva porquanto não precisa de nossa crença para existir, pois sua existência nós a vislumbramos ali mesmo onde suspendemos nosso juízo. Essa realidade efetiva aparece quando o silêncio daquela suspensão pode ser também concebido como a origem de toda e qualquer linguagem erguida porventura como forma de descrição do que aparece, vindo do fundo daquele silêncio, fundo absoluto e absoluta forma. 
Essa tarefa de desvelamento, desdobramento ou desenvolvimento do ponto de origem, não pode, porém, ser realizada seguindo-se a autoridade de Sexto Empírico, porque segui-la seria manter-se num nível de pensamento que, incorrendo sempre naquela atitude descrita por Hegel, na Fenomenologia, como a do "falatório" de dois rapazes teimosos numa discussão infindável (HEGEL, 2011, p. 158), apenas repetiria as retrancas céticas. ${ }^{2}$ O cético se recusaria a ser dogmático, sem nada fazer de efetivo contra os dogmáticos, ao passo que uma posição dogmática é sempre uma violência contra o direito de se assentar uma posição cética, como aliás qualquer outra passível de contrariá-la. Tais retrancas deixam-nos sem poder tirar o devido proveito do próprio ceticismo em favor de uma posição universalista radical, sem chance para dogmatismos, porém suficientemente plástica para que os dogmáticos possam à son guise fazer seus assentimentos, contanto que, desta feita, sejam eles a ficarem na retranca, já que a universalidade de um dogma será, nessas circunstâncias, sempre a universalidade de uma posiçáo publicamente unilateral.

Trata-se, como se percebe, de uma estratégia para tomar das mãos dos dogmáticos o conceito de universalidade, e é por isso que nossa posição de pensamento será pouco entendida, se for vista como uma forma de relativismo. Não é, como procuraremos deixar claro a seguir. A ser, pois, assim, a nossa leitura consistirá em buscar o flanco pelo qual possamos ver em estado de trabalho o objeto da busca cética (a verdade das coisas, que o cético, embora sem esperança de apreendê-la, reconhece existir quando anseia por ela). Ao vislumbrar essa verdade como objeto, ou melhor, como campo, e não como qualidade de uma proposição, podemos nos colocar no centro do "caráter distintivo do ceticismo" (a suspensão da crença), mediante o encontro do que já não precisa de crença, porque é efetivamente. Por essa estratégia de pensamento o cético não teria mais de pedir ao dogmático o direito de poder suspender sua crença, mas poderia doravante dar a este último o direito de sustentar a sua, porém, de antemáo, deixando evidente tratar-se de uma mera crença

\footnotetext{
${ }^{2}$ Por retranca cética compreendo a atitude pela qual se dá certo recuo em face da radicalidade universalista possível ao ceticismo, em favor do individualismo, que apenas reivindica o direito de uma posição entre outras, deixando aos dogmáticos o campo livre para afirmar coisas que nenhum cético sustentaria, contra o próprio cético e seu direito de suspender o juízo. Que se leia, a propósito, esta passagem emblemática: "Nossa atitude é similar quando dizemos 'Tudo é inapreensível': explicamos 'tudo' na mesma forma, e suprimos 'para mim'. Logo, o que é dito é isto: 'Tudo dentre os assuntos pouco claros investigados pela maneira dogmática os quais tenho investigado aparece a mim inapreensível.' Isto não assenta uma afirmação de que os assuntos investigados pelos dogmáticos sejam de uma tal natureza a serem inapreensíveis." (SEXTO EMPÍRICO, 2000, p. 50).
} 
sustentada, um asseverar perfeitamente confrontável com outro, oposto, sem que nenhum desses assentimentos trisque sequer algo mais do que um lado da verdade das coisas (entretanto, jamais toda a verdade que, por permitir ambas as crenças e também a suspensão do juízo, estará sempre aquém e além de qualquer determinação última). Toda determinação última posta em cena seria vista como forma - sempre potencialmente violenta - de calar o adversário.

O assentimento dogmático será por isso produto de um relativismo a contragosto, visto que quem diz um lado da verdade está sempre querendo passar a impressáo de dizer a verdade toda, como se dizer toda a verdade fosse possível no mero ato de asseverar; mas, em verdade, não dirá senão, de cada vez, um lado tomado como um todo.

A estratégia aqui proposta, ao contrário, seria uma espécie de pós-ceticismo. Desse modo, é preciso ir contra a autoridade de Sexto Empírico, porém na direção de onde ele vem: por uma espécie de fidelidade a contrapelo. Vamos explicar isso. Contra Protágoras (assim como contra Heráclito), que anteviu o fundo sem fundo que pode ser divisado sob a suspensão do juízo, e a firmou tratar-se de um fluxo inapreensivel, ele escreve: "Vemos, pois, que ele sustenta crenças sobre a matéria estar em fluxo e sobre a presença nela das razóes para todas as coisas aparentes [...] Mas essas coisas são pouco claras e nós suspendemos o juízo sobre elas.” (SEXTO EMPÍRICO, 2000, p. 56s). A objeção é, na verdade, fraca. Não há nada de pouco claro nisso. Trata-se, antes, de renitência de sua parte. Se o "carácter distintivo do ceticismo" (SEXTO EMPÍRICO, 2000, p. 58) é não ter crença (senão no que aparece), não se deixa de ser cético ao reconhecer, por baixo das múltiplas aparências das coisas, aquilo que garante essa aparência efetiva em sua multiplicidade, e o faz independentemente de ter ou não nossa adesão a ela, pois, se a multiplicidade do aparente é um fato, um efeito (consumado pela equipolência das afirmaçóes sobre ele e da consequente suspensão do juízo), então sua causa estaria assegurada na própria produção e reprodução do efeito, sem que a afirmação "eu acredito nisso" ou "eu não acredito nisso" pudesse mudar o estado dessa eventualidade do múltiplo ou, mais precisamente, pudesse mudar o múltiplo como um evento inarredável. Não se trata, por conseguinte, de um asseverar da crença de haver o múltiplo, mas de observar essa coisa única em sua unicidade absoluta e sensível: há o múltiplo naquilo que aparece.

Ora, é possível provar ser dessa recusa teimosa de aceitar o reconhecimento da "coisa única" (a verdade como o múltiplo do que aparece), que a busca cética (zétesis) procurava, recusa de aceitá-la e reconhecê-la como final- 
mente vislumbrada (a verdade das coisas sem necessidade de se crer nela) que segue a postura conservadora do ceticismo pirrônico:

\begin{abstract}
Pois os Acadêmicos dizem que as coisas são boas e más não do modo como fazemos, mas com a convicção de que é plausível que o que eles chamam de bom mais do que o seu contrário é realmente bom (e similarmente com o mau), ao passo que nós não chamamos nada de bom ou mau com o pensamento de que o que dizemos seja plausível - antes, sem sustentar opinióes seguimos a vida ordinária com o fito de não sermos inativos. (SEXTO EMPÍRICO, 2000, p. 60).
\end{abstract}

Seguir a vida ordinária, sem aparentemente questioná-la, eis o que entendo por postura conservadora do cético pirrônico. Mas, muito embora, à página 63, possamos justamente ler ser esse apego à vida comum, cotidiana, às leis e costumes estabelecidos e aos "sentimentos naturais" consistente em deixar-se guiar "pela natureza" [guidance by nature, yphegései physeos], (SEXTO EMPÍRICO, 2012, p. 61), a referência à physis entrega-nos aquilo mesmo prestes a permitir a multiplicidade das coisas aparentes; aquilo diante do que se pode tanto afirmar algo quanto o seu contrário e, ainda assim, também suspender o juízo e anular, desde a raiz, porquanto unilateral, qualquer posicionamento dogmático como algo sempre forçosamente "relativo".

Ou seja, o flanco pelo reconhecimento da verdade buscada sem necessidade de sustentar-se uma crença ou um juízo sobre ela garantiria ao ceticismo, eis nossa tese, a possibilidade de ele permanecer ceticismo (trabalho de pesquisa), mas, desta feita, sob duas novas feiçóes: (1) sob um inusitado universalismo radical; e (2) sem precisar ater-se conservadoramente aos costumes arraigados, como sói acontecer com os céticos históricos. Permanecer ceticismo sob um universalismo radical significa atestar a qualidade filosófica do ceticismo, ao mesmo tempo em que se prepara uma crítica filosófica da filosofia, a fim de, ao apontar para a unilateralidade de cada uma das filosofias existentes, cujo universalismo por elas defendido, de cada vez, sempre pode ser reduzido, seja ao universalismo da substância, no caso da aposta histórico-filosófica de um projeto de mundo (e de racionalidade) baseado no primado da comunidade sobre o indivíduo, seja ao universalismo do sujeito, no caso da aposta inversa, de um projeto baseado no primado do indivíduo sobre a comunidade, graças à ideia de uma razão subjetiva (ANDRADE, 2016), poder abrir o campo de cogitaçóes capazes de ponderar sobre cada uma dessas apostas como meras propostas de projetos de habitar o mundo, e não mais como descrição fiel de um mundo dado em absoluto. 
Essa qualidade filosófica do ceticismo - gostaríamos de mostrar - entregaria a filosofia à filosofia, e conduziria o pensamento ao ponto vivo (lógico ou transcendental) de onde brotam todas as criaçóes da natureza e do espírito, unificando as condiçóes de possibilidade de um projeto de mundo e de existência dentro do qual o fazer-se da história, onde a intolerância seria o único intolerável, se daria como abertura para a posição de novas questôes, logo, também, de novas formas de filosofia como também de outras manifestaçôes espirituais extrafilosóficas ${ }^{3}$, sem as hierarquias surgidas desde o primado da ciência e do tipo de sociedade que esse primado organiza, quando se refuta muito ligeiramente o ceticismo.

Para chegarmos a esse ponto único de variação infinita ("a imensa variedade que a natureza sempre manifesta em suas operaçóes", como diz Hume, mas também a imensa variedade de formas sociais de vida e, portanto, de filosofias e de conversações, sem medo do conflito, entrementes sempre a postos), forçoso é, no percurso oposto ao de Enesidemo e de Sexto Empírico, irmos, entâo, ao encontro de ambos. Ao encontro, porque faremos, notadamente, uma leitura do capítulo XIV, dos "Dez modos", do Livro I das Hipotiposis pirrônicas, de Sexto, sobre o qual, com razão, escreveram J. Annas e J. Barnes (2003, p. 21) que era "uma parte central e lancinante (striking) da filosofia pirrônica". No entanto, no percurso oposto, porque faremos uma leitura a contrapelo, indo da intenção do autor (ao dizer o que diz) em direção ao próprio dito, a fim de explicitar no dito a ganga de não-dito que se agrega a ele, involuntariamente, exigindo mais, e não menos atos de pensar.

No que segue, a propósito, daremos por conhecidas as detalhadas observaçôes eruditas desses dois autores ingleses, bem como as do francês Victor Brochard (2009) e a leitura seletiva, porém instrutiva, acerca da estratégia de demonstração dos tropos, feita por Paul Woodruff (2010). Em todo caso, atentos a suas informaçôes durante nossos comentários ao texto de Sexto sobre

${ }^{3}$ Cf. Hume (1992, p. 159): "Alimentei durante muito tempo certa desconfiança em relaçấo às decisóes dos filósofos sobre todos os assuntos, e encontrei em mim próprio mais tendência para contestar suas conclusôes do que conceder-lhes meu assentimento. Há um erro a que todos eles, quase sem exceção, parecem sujeitos: limitam excessivamente seus princípios tornando-se incapazes de dar conta da imensa variedade que a natureza sempre manifesta em suas operações." 
os tropos de Enesidemo, deles nos distanciaremos, principalmente devido ao fato de todos estarem muito ciosamente preocupados com a forma do argumento, e não propriamente com seu conteúdo. Annas e Barnes chegam mesmo a duvidar se Sexto acredita na verdade das informaçóes por ele usadas para construir seus argumentos contra os dogmáticos. Nós, todavia, privilegiando, de partida, o texto de nosso Autor, e deixando de lado as variaçóes de Diógenes Laércio e de Philo de Alexandria, que são também tratados por Annas e Barnes, tentaremos mostrar tanto na forma quanto no conteúdo do argumento, quando lidos a contrapelo, o texto de Sexto como lugar retórico de aparecimento daquilo mesmo que nos interessa ver e fazer ver em sua exuberância imaginativa, que dá o que pensar, e que vimos chamando de verdade como campo, de logos, de psique, palavras diferentes para uma mesma noçáo a ser posta e exposta.

Antes, ainda, de entrarmos no estudo dos modos ou tropos do ceticismo, convém dizer seguiremos, não a ordem do texto, ou a chamada "árvore" (ANNAS; BARNES, 2003, p. 26) de Sexto, a saber, a forma possível de agrupar os tropos, considerando menos a ordem numérica em que aparecem que a ordem dos gêneros ( $a, b, c)$ e espécies ( $1,2,3$ etc.), assim: (a) relativo a quem julga $(1,2,3,4)$; (b) relativo ao objeto julgado $(7,10)$; e (c) relativo a ambos $(5,6$, $8,9)$; mas, com vistas a uma detença mais ciosa àquele que Victor Brochard, secundando Sexto, em seu comentário a Enesidemo, designa de "o gênero supremo" (BROCHARD, 2009, p. 266), o da relação, procuraremos oferecer uma leitura capaz de permitir perceber a oposição, herdada dos sofistas, quando expressa em termos da diferença entre physis e nomos; ou da tradição aristotélica, ${ }^{4}$ quando pensada na unidade de forma e matéria como psique (o devir lógico dos seres vivos), ${ }^{5}$ que se bifurca entre um lado passivo (patetikos) e um lado ativo (poiétikos) (CASTRO, 2008, p. 106). A saber: leremos primeiro os tropos que recorrem ao material relativo à natureza e, em seguida, trabalharemos com os que dizem respeito aos costumes, porque assim (julgamos) poderemos recuperar o fio vermelho de nossa discussáo maior, e suspender o trabalho de análise no momento em que surgir o tema da dialética da continuidade e da descontinuidade entre o poder da physis e o poder da póiesis.

\footnotetext{
4 "Aristóteles é sem dúvida a fonte última de algumas das informações de Sexto." (ANNAS; BARNES, 2003, p. 41).

5 "A palavra psique significa 'vida' (ela é derivada do verbo psichein, 'respirar, explodir'), e era universalmente aceita como fonte de toda consciência e de toda vida.” (NADDAF, 2005, p. 66).
} 
Esse momento, no comentário de Brochard, aparece quando, depois da exposição dos tropos de Enesidemo, ele segue bravamente para traçar, sobre a verdade e a certeza, uma relação entre ceticismo e ciência, o que o ocupa até a conclusão de seu livro, e o que dá especificidade a seu trabalho e a sua contribuição aos estudos céticos. Nossa ideia, porém, é, ao chegar ali no mesmo ponto em que ele chegou, derivar para traçar a questão da verdade, num sentido outro que não o epistemológico. ${ }^{6}$

A verdade não-epistemológica seria uma experiência viva do campo de relaçóes de sentidos em contexto de socialização. Chamemo-la psique, ${ }^{7}$ como o todo de um desbravamento que vai da physis a seu desdobramento descontínuo, como póiesis, ethos, héxis, nomos. ${ }^{8}$ Talvez possa haver aí certa aparência de dogmatismo de nossa parte, mas contra isso sempre poderemos contar com a própria expressão de Brochard, a saber, a de "dogmatismo mínimo", que ele mostrou existir inclusive em Enesidemo. Mas, se dogmatismo vier a ocorrer, será um dogmatismo do silêncio (ou da escuta), pois, sob esse silêncio, jaz o vazio poderoso, o nada movente que, no fundo, não é bem "nada" exatamente, a saber, não é uma pura ausência, porque é o próprio fluxo da natureza, o ser (psique), o poder criador (poiétikos) que, todavia, não é uma coisa, no sentido de uma objetividade determinável ou determinada, porém é a pura espontaneidade inventiva da natura naturans e do trabalho abstrato, que não vemos "em si", mas que nos aparece em seus produtos, a fauna, a flora, os astros, os minérios, por um lado; a caverna, os rituais, a linguagem, os painéis de pintura rupestre, a cabana, as pirâmides, a Vênus de

${ }^{6}$ Neste ponto é válido confrontar o que segue com o que é exposto e defendido por Oswaldo Porchat, no ensaio Saber comum e ceticismo (PORCHAT, 2007, p. 74-88). Porchat pretende radicalizar a posição cética, fincando pé no mundo e na vida comuns, para ele irredutíveis às teses que se possam erguer a partir desse mundo e dessa vida sobre esse mundo e sobre essa vida. O que ele, todavia, não entende ou não percebe é que o próprio mundo e a própria vida comuns a que ele se recolhe foram postos, podendo por isso serem contrapostos por outra constituiçấo de mundo "comum" e vida "comum". Veremos adiante que, ao chegarmos a nosso ponto, alcançaremos um "lugar" de constituiçáo de mundo muito mais radical, porquanto não será uma coisa posta (pragmata), porém um ato contínuo de posição (e deposiçấo), a que chamaremos de sentido poético da sociabilidade.

7 Dir-se-ia que isso é aristotélico, e não cético? Não queremos nos ater à ortodoxia aristotélica. Mas saber, pela leitura de Susana Castro (2008), que é possível trilhar rumo a uma doutrina da substância convergente com esse ponto único, a psique (que é duplo), é, no mínimo, animador, na medida em que a tese de Castro é, por si mesma, filosófica (e não um simples tratado sobre um tópico aristotélico). De qualquer modo, do ponto de vista da história da filosofia, pelo menos em termos de Ética, "os oponentes de Aristóteles não são os céticos, mas os convencionalistas.” (ANNAS; BARNES, 2003, p. 159).

${ }^{8} \mathrm{Cf}$. Vaz (1988), quanto ao uso dessas palavras; e, quanto ao horizonte ontológico aqui visado, cf. Fiori, (2014), cuja ontologia, retirada de seu quadro referencial católico-cristâo, converge admiravelmente para nossa própria posição de pensamento, entrementes, ainda em estado nascente. 
Milo, o arranha-céu, a obra de Picasso, as pedras de paralelepípedos nas ruas etc., por outro, bem como aquelas moças de cabelos azuis; aquelas outras de pescoço alongado por uma argola; aquele povo que faz da música sua forma de sociabilidade; aquele outro para o qual nenhuma morte é natural, e faz da vingança de sangue a religiosidade com a qual organiza o todo de sua vida social; aquele outro, ao invés, que, em dois dias, são convidados a esquecer a morte de um ente querido etc. - "nada" que aparece como "algo" em seus produtos, e do que outra coisa mais que isso não se pode dizer, sob pena de anular aquilo mesmo que se estará tentando mostrar.

A esse respeito, de qualquer modo, e para quem exigiria já aqui algo mais concreto, a melhor representação disso para o que estamos apontando seria uma obra de Yves Klein, O vazio (Le vide, de 1932), que consiste na maravilhosa exposição de uma galeria de arte pintada de branco, sem coisa alguma a ser exposta, a não ser o nada, o próprio vazio. Ora, essa obra pode ser considerada a mais completa obra de arte jamais concebida em toda a história da Arte, uma vez que, nela, por nada haver de determinado, estar inscrita não só todas as formas de arte presentes, passadas e futuras, como também todas as obras possíveis e imagináveis. Ali onde se veria apenas o vazio, é na verdade apenas a representação do vazio divino de onde brotam todas as obras da natureza e dos seres humanos. Ao propor essa instalação, Klein nos forçava a ver o Absoluto, esse instante em que nada aparece, porque é a condição de possibilidade de todo aparecer de algo, de toda aparência e, portanto, de todo o ser, contudo, sob a forma indeterminada de um vazio, de um nada cheio de virtualidades.

Se colocamos o "nada" (o indeterminável) assim concebido como princípio (o que equivale a livrá-lo de uma calúnia, aquela de ele ser uma "miragem da ausência"), qualquer outra apresentação de princípio (determinado) será forçosamente sempre unilateral e, por isso mesmo, relativa, dependente, pouco verdadeira, ou verdadeira apenas para quem se dispóe a aceitá-la dentro de um certo projeto de mundo.

Com isso tornado público, isto é, com o dogmático sabendo que, no fundo, há só o que não pode ser determinado, quando ele determina algo, ele sabe que os outros sabem que ele está simplesmente tentando forçar uma universalidade, um esticar de seu princípio sobre as demais formas de pensamento como meio de fazer valer apenas o seu próprio pensamento; ele sabe que os outros sabem que ele está sendo unilateral com sua "universalidade" mereológica (manca, porquanto defensora de apenas um dos muitos lados sempre 
possíveis e passíveis de serem desdobrados); ele sabe que os outros sabem ou podem vir a saber que ele, ao querer substituir o vazio por um ser determinado (o "Deus" judaico-cristão, por exemplo, ou o "sistema da ciência"), ele estará sendo, ou muito honesto, quando se mantém em sua tribo ou época, ou muito desonesto, quando quiser que todos o sigam numa mesma e presumivelmente única direção (salvacionista, seja pela lei, seja pela ciência, ou outro valor), porque, ainda para ficarmos no exemplo, o "Deus" judaico-cristão é pragmata, como as línguas, os sistemas de parentescos, os mitos, a noção de "história" e também a noção de um "sistema", isto é: coisa feita boa para fazer render um projeto de mundo.

Contra essa e outras universalidades "mereológicas", sejam observados cf. Sexto Empírico (2000, p. 13, 25, 32s), num primeiro olhar, os tropos 1 (a diversidade dos animais); 3 (a diversidade dos sentidos); 6 (as misturas); 7 (as quantidades ou composiçóes); 9 (a frequência e a raridade), do lado da physis; e, em seguida, os tropos 2 (as diferenças entre os seres humanos); 4 (as circunstâncias); 5 (as situaçôes, as distâncias e os lugares); 8 (a relação) e 10 (os costumes, as leis e as opiniôes), do lado da póiesis, do ethos, do nomos. Modos de argumentação do ceticismo, é de se entender sejam os tropos, primeiramente, lidos numa perspectiva epistemológica, no sentido em que são postos em ação a fim de se verificarem a possibilidade e os limites da ciência em geral. Daí também os estudiosos, como dissemos, tentarem classificá-los em tropos que (a) tratam do sujeito; (b) tratam do objeto; e (c) tratam de ambos. Todavia, como aqui é outra a nossa visada, o desenvolvimento da análise há de justificar a escolha de reduzi-los à dupla perspectiva physis-póiesis, na qual se pressupóe uma relação (psique) de continuidade e descontinuidade entre os pares da dupla referida.

Para efeito de uma primeira exposiçáo, tomaremos a liberdade de reproduzir aqui, mas segundo a ordem indicada acima, a providencial tradução de Jaimir Conte do livro de Brochard (à época de sua primeira edição, lido saborosamente por Nietzsche), quando resume os tropos de Enesidemo, gravados no texto de Sexto Empírico. Em seguida, contudo, voltar-nos-emos mais livremente para o próprio texto de Sexto, quando nos concentraremos no primeiro e no último dos tropos, para melhor averiguar a dialética da continuidade e descontinuidade entre physis e póiesis:

$1^{\circ}$. A diversidade dos animais. - Há numerosas diferenças entre os animais: nem todos nascem da mesma maneira, nem todos têm os mesmos órgáos. Ora, sabe-se que uma modificação do órgão, como a icterícia no homem 
ou a ação de esfregar os olhos, modifica a percepção. Portanto, quando se veem animais que têm uma luz nos olhos ou a pupila dilatada, é forçoso admitir que suas percepçóes diferem das nossas. Deve-se dizer o mesmo dos outros sentidos: o tato não é o mesmo para o que está revestido de uma concha, de penas ou de escamas; o sabor não é o mesmo para o que tem a língua seca ou úmida. A observação, aliás, atesta essa diversidade de percepçóes: o azeite, que é bom para os homens, mata as vespas e as abelhas; a água do mar é um veneno para o homem, se ele a usa durante muito tempo, mas é assaz agradável aos peixes. Sendo assim, de um objeto conhecido pelos sentidos nós poderemos dizer como ele nos aparece, mas náo o que ele é, afinal, com que direito podemos supor que nossas percepçóes são mais conformes à natureza das coisas que as dos animais? (BROCHARD, 2009, p. 262).

Façamos, nesse ponto, o seguinte registro: o historiador francês também resume a defesa dos animais feita por Enesidemo e Sexto, contra a alegada (pelos dogmáticos) superioridade dos seres humanos em relação aos outros animais; observemos ainda: de fato, embora não possamos decidir entre o que é e o que aparece, não é, por isso mesmo, improvável que o que é se dê como a própria diversidade das aparências. A "causa” (o ser dos efeitos) estaria inscrita na efetividade do efeito (as aparências), e não seria mero agente de efetuação a desaparecer mecanicamente "por trás" dos efeitos, mas "daria o ar de sua graça" ali mesmo onde, sem ser vista separadamente, se mostra inteira nos efeitos das múltiplas aparências. A causa seria o próprio caso. ${ }^{9} \mathrm{E}$ isso de algum modo se deixa explicar pelo tropo de número 3:

$A$ diversidade dos sentidos. - Dir-se-á que [...] é preciso fiar-se em um só homem tomado por juiz, o sábio ideal do estoico, por exemplo? Este se encontrará inteiramente perplexo para decidir, já que encontrará entre os diferentes sentidos uma nova diversidade. Uma pintura tem relevo para os olhos e não o tem para o tato. Um perfume agradável ao olfato desagrada o paladar. A água da chuva, boa para os olhos, enrouquece e incomoda os pulmóes. Quem sabe se as qualidades das coisas náo dependem unicamente da diversidade dos órgáos? Uma maçã talvez tenha uma só qualidade; talvez possua mais qualidades do que aquelas que conhecemos: podemos

\footnotetext{
9 Por ora, uma imagem talvez seja suficiente para dizermos o que temos em vista. Que se olhe uma "floresta": aroeira, bracatinga, canafístula, dedaleiro, fedegoso etc. Qual a causa de tanta variedade de árvores diferentes? Qual a causa de uma floresta? A própria variedade de árvores, e a fotossíntese, ali presente em cada uma e em todas, e nem por isso visível, senáo em seus próprios efeitos, como floresta, como diversidade botânica. Dir-se-á que ninguém está seguro sequer de haver ali uma floresta, quanto mais a fotossíntese? Ceticismo, então, seria o mesmo que puerilidade? Não acreditamos nisso. Mesmo que aquilo que apontamos como "floresta" seja apenas uma aparência de floresta, é uma aparência que aparece como floresta, e nấo como outra coisa.
} 
ignorá-las como o cego ignora as cores. Portanto, aqui também, vemos apenas a aparência, não a realidade. (BROCHARD, 2009, p. 263).

Vemos apenas aparência, não a realidade; e acrescentamos: a não ser a realidade de que vemos apenas a aparência. Sob a aparência, ademais, o que $e ́$ nos toca somente na medida de nossas capacidades de sermos tocados; ou, dizendo de frente para trás: nosso contato com as aparências das coisas que são não esgota a apreensão possível daquilo que é das coisas que são, senão na medida em que nos conformamos à circunscrição do aparecimento do aparente. Poder-se-ia dizer: o ser se mistura ao que aparece como a causa se mistura aos efeitos. Nessa circunscrição, portanto, o que sobressai é a mistura. E o sexto tropo trata justamente disso:

Um objeto jamais nos aparece sozinho, mas sempre unido a alguma outra coisa: ao ar, ao calor, à luz, ao frio, ao movimento. Como conhecer o objeto em si mesmo nessa mistura? A cor de nosso rosto parece diferente quando faz frio. Nossa voz náo tem o mesmo som num ar rarefeito e num ar denso. A púrpura náo tem a mesma cor ao sol e sob a lâmpada. Por outro lado, nós não conhecemos as coisas senão por intermédio de nossos órgãos, nova união que altera a percepção. [...] Não podemos separar as coisas daquilo que as cerca, assim como não distinguimos o azeite num unguento. Mas não separá-las é não conhecê-las em si mesmas. (BROCHARD, 2009, p. 264).

Porém, esse experimento de pensamento impóe concebamos em si mesmas as coisas como misturas. O sétimo tropo (o das quantidades ou composiçôes) nos ajuda a confirmar essa compreensáo:

As coisas mudam de aspecto conforme sejam tomadas em maior ou em menor quantidade. Considere separadamente os chifres da cabra apontando: eles parecem brancos; considere os chifres formados: eles são pretos. Os grãos de areia, separados, parecem ásperos; no monte, parecem suaves. O vinho fortifica se o bebemos com moderação; ele debilita-nos se o bebemos exageradamente. (BROCHARD, 2009, p. 264).

Ou seja, se um diz a coisa lhe parece de um modo e sustenta sua posição, o outro logo há de dizer seu contrário com o mesmo vigor e a mesma fonte de sustentação: a aparência. $\mathrm{O}$ cético suspende o juízo; não afirma nem uma coisa nem outra e, ao fazê-lo, que permite ele ver, quando, levantado o juízo, as aparências correm soltas? Permite seja visto o próprio ser como essa mistura 
daquilo que ele é, em si, enquanto inapreensível, e, para nós, nos limites estreitos de nossa capacidade de apreensão. A verdade, nesse âmbito, não seria nem o sustentado por um, nem o contradito por outro, mas o que se deixa ver quando o juízo é suspenso, isto é, quando o silêncio impóe a força de as coisas serem capazes de aparecer sob uma multiplicidade de focos diferenciados. Este, aparentemente, o ponto do nono tropo, sobre a frequência e a raridade:

Um cometa nos assombra porque aparece raramente; o sol nos assustaria se não o víssemos todos os dias. Não nos inquietamos mais com os tremores de terra uma vez que estamos habituados a eles. Logo, não são as características das coisas em si mesmas que decidem nossos juízos, mas sua frequência ou sua raridade: nova prova de que só alcançamos as aparências. (BROCHARD, 2009, p. 265).

Alcançamos apenas as aparências ou a efetividade, isto é, o estado de ser e de verdade de que, não se podendo ficar ou com uma forma da coisa ou com outra, restaria a coisa mesma sendo, na unidade de seu ser, o próprio diverso do aparente como multiplicidade. Ou seja, a experiência com a verdade não é da ordem da proposição sobre um dado estado de coisas, mas da percepçáo e do reconhecimento tácito do primado da multiplicidade sobre a unidade, o que empurra o pensamento a conceber um princípio cujo estofo seja da ordem da ausência (para assegurar a multiplicidade), e não da presença (que asseguraria o primado do uno, daria razão ao dogmático, e reduziria em última instância o múltiplo a uma unidade improvável). Mas a ausência, aqui, não é a falta, porém o lastro onde presenças possíveis e reais pululam.

Isso quanto às coisas naturais. Sejam observadas agora as coisas humanas. O segundo dos dez tropos, sobre as diferenças entre os seres humanos, diz: "Concedamos, porém, que os homens são superiores aos animais. Há tantas diferenças entre eles que ainda estaremos na impossibilidade de decidir onde está a verdade." E continua:

Os corpos diferem pela forma e pelo temperamento: viu-se uma mulher ateniense beber trinta dracmas de cicuta sem sentir-se mal por isso. Demofonte, servidor de Alexandre, sentia frio ao sol, ou no banho, e calor na sombra. Os espíritos não diferem menos: uns amam a vida ativa, outros, o repouso; todos os poetas assinalaram essas oposiçóes. Como escolher entre tantas aparências diversas? Ater-se ao maior número? Mas não conhecemos todos os homens, e aquilo que aqui a maioria pensa náo o pensa em outro lugar. É melhor não escolher e não afirmar nada. (BROCHARD, 2009, p. 263). 
Nada, a não ser o que acaba de ser dito: a diferença e a variedade precedem o juízo que, de uma das coisas diferentes, afirmaria uma delas como mais verdadeira que a outra. Ao suspender o juízo, do fosso do silêncio assim aberto dá para ver, lá no fundo, a verdade como justamente aquela diferença sem termo e aquela variedade sem esgotamento. $\mathrm{O}$ tropo 4, das circunstâncias (peristáseis), cuidaria de qualificar esse estado de coisas.

Com este nome (peristáseis) o cético designa os hábitos, as disposições ou condiçōes particulares que fazem variar as percepçōes: tais são a vigília ou o sono, as diferentes fases da vida, o repouso ou o movimento, o amor ou o ódio. O mel parece amargo aos que tem Icterícia. Àqueles que têm um sangramento, um tecido parece cor de sangue, enquanto nós o julgamos totalmente diferente. Não cabe objetar que esses são casos anormais e de doenças, pois como saber se, em plena saúde, não estamos em condiçóes aptas a modificar a aparência das coisas? Assim também, o amor nos faz ver a beleza onde ela não existe. Não se tem as mesmas ideias quando se está embriagado e quando se está sóbrio. Como decidir entre essas aparências? Todas se equivalem. (BROCHARD, 2009, p. 263-264, grifo nosso).

Entre a afirmação possível de uma tese, e a de outra oposta igualmente válida, a suspensão do juízo conduz a uma terceira, mais verdadeira, porque não olha para os lados, mas para a fonte mesma da verdade: em meio ao diverso, tudo se equivale. Alguém poderia, prematuramente, neste ponto, objetar: se tudo equivale, onde ficam os valores morais, a necessidade de pôr limites a práticas hediondas? A esse alguém, pediríamos um pouco de paciência, e que olhe menos para seu umbigo e mais para a coisa mesma. Ou, então, pediríamos fosse relido o Tratado da natureza humana, de Hume, onde a moral não é tomada como um conjunto de preceitos universais, mas como a disposição universalmente partilhada por grupos humanos para decidir, entre seus membros, quais práticas serão escolhidas como boas; quais, como abomináveis, não segundo a ordem da razáo, mas desde a desordem dos afetos.

O tropo de número 5, das situaçóes, das distâncias e dos lugares, irá enfatizar "a coisa mesma", a efetividade do diverso originário contra a aparência de unidade unilateral:

Um navio visto de longe parece pequeno e imóvel, visto de perto, parece grande e em movimento. Uma torre quadrada vista de longe parece redonda. Isso quanto às distâncias. Um remo parece quebrado na água e reto fora. A luz de uma lâmpada parece apagada ao sol e brilhante nas trevas. Isso quanto aos lugares. Uma pintura tem relevo se a olhamos de longe: ela parece lisa se a olhamos de perto. O pescoço das pombas se matiza em mil 
cores diferentes conforme elas se voltam para um lado ou outro. Isso quanto às posiçóes. Como, porém, conhecer as coisas, abstração feita do lugar que ocupam, da distância em que nos encontramos, da posição que assumem? Portanto, nós não as conhecemos. (BROCHARD, 2009, p. 264).

Sabemos com certeza apenas da diversidade como um fato tanto mais visível quanto menos ajuizamos por uma ou por outra das possibilidades de aparecimento de uma mesma coisa. Nesse ponto, o encontro entre a forma da pintura (do lado da póiesis) e as cores do pescoço de uma pomba (do lado da physis) traz a diversidade geral para o cadinho da própria dualidade natureza-cultura. Póiesis e physis se roçam e se tramam aqui, na unidade plural da própria diversidade como único fato verdadeiro. Isso nos convida a pensarmos a noção de psique como um crisol de relaçôes de relaçóes (se já agora pensamos a "coisa" náo como um dado, mas como o conjunto das relaçóes que a constitui a partir de dentro de sua própria aparição): é o tropo 8.

Cada coisa é ao mesmo tempo relativa a outras coisas, com as quais é percebida, e àquele que percebe. Uma coisa não está à direita ou à esquerda em si mesma, mas somente em relação a outra. O dia é relativo ao sol. Da mesma maneira, o alto é relativo ao baixo, o grande ao pequeno, o pai ao filho. Nada é conhecido em si mesmo (BROCHARD, 2009, p. 265),

a não ser se pensamos que o "si mesmo" (a psique) seja essa própria relação. E é, com efeito, quando pensamos o ser e o verdadeiro como "relação" (isto é, conjunto de elementos em recíproca afetaçáo) que melhor podemos entender o décimo tropo (dos costumes, das leis e das opinióes):

Já não se trata aqui das sensações, mas das crenças morais: elas variam ao infinito. Os egípcios embalsamam seus mortos, os romanos os queimam, os peônios os lançam nos pântanos. Os persas permitem que os filhos se casem com as mães; os egípcios, que os irmãos se casem com suas irmãs; a lei grega o proíbe. Quantas diferenças entre as diversas religióes, entre as opiniôes dos filósofos, entre as narrativas dos poetas! Portanto, pode-se dizer que os homens pensaram sobre este ou aquele ponto o que lhes pareceu verdadeiro, não o que é verdadeiro (BROCHARD, 2009, p. 265),

pois o que é verdadeiro não é um ponto ou outro isolado, mas a própria "variação infinita" dos pontos na multiplicidade de suas relaçóes como um todo unitário e, entrementes, desdobrável, primeiro, em dois (physis e póiesis), e depois, dentro de cada um desses elementos, em miríades de produtos 
e de suas relaçôes, um perfazendo o mundo físico, outro, na exploração desse mundo, perfazendo o mundo social e cultural na rica pletora de suas manifestaçôes variadas sobre a vasta superfície da Terra.

A esta altura, onde a dinâmica da verdade, aquém dos juízos e proposiçôes de universalismos partidaristas (mereológicos), deixa-se ver numa região anterior a toda predicação como "variação infinita" de pontos em múltiplas relaçóes na unidade disjuntiva de natureza e cultura (ou a unidade da psique como um todo desdobrável de relaçóes de relaçóes), ou de physis, por um lado, e do complexo humano de póiesis, ethos, héxis e nomos, por outro, podemos agora limitar nosso foco a dois (o primeiro e o último) dos dez tropos, seguindo desta feita a leitura do escrito do próprio Sexto Empírico.

Esse texto assim se inicia: "Primeiro, dissemos, é o argumento de acordo com o qual os animais, dependendo da diferença entre eles, não recebem as mesmas aparências das mesmas coisas. Disso deduzimos cada uma das diferenças na forma na qual eles são produzidos e na variação na composição de seus corpos" (SEXTO EMPRÍRICO, 2000, p. 13), ${ }^{10}$ para deixar mais viva a impressão de efetividade do diverso perseguida pela exposição sextina, porque é essa "efetividade", mais que o próprio "diverso", que assegura a possibilidade de falarmos, sem dogmatismo, ou com um dogmatismo mínimo, de unidade, identidade, verdade como experiência única do plural. ${ }^{11}$

Observemos a primeira rubrica de seus argumentos: diferença nas formas de engendrar-se dos animais (SEXTO EMPÍRICO, 1993, p. 66). Perceba-

\footnotetext{
${ }^{10}$ Sexto Empírico (1912, p. 10): Próton elégomen einai lógon kath'ón <pará> tén diaphoràn tón zóon óukh ai autái apó tón autón hypopipitousi phantasiae [...]. Nesse ponto, a edição espanhola passa a ser também bastante útil, devido às seçôes temáticas que ela abre para cada um dos argumentos de Sexto. Cf. Sexto Empírico (1993). Todavia, continuaremos o cotejo com a ediçấo inglesa, citando-as entrelaçadamente.

${ }^{11} \mathrm{O}$ plural precede os nossos juízos de valores e aquilo que, para nos singularizarmos enquanto um grupo específico, escolhemos como o que é o mais desejável e, por isso, o mais alto, tanto quanto o que é mais abominável e, por isso, o mais baixo. Não custa, porém, lembrar: a própria noção de que o "baixo" seja pior que o "alto" também já é um simbolismo que veio a ser (criado), de modo que a ânsia por elevar a universalidade de nossas escolhas, aquela que nos faz sentir membros do grupo a que pertencemos, à universalidade única, boa para todos os demais grupos humanos, não é uma conquista da Lógica, porém uma ambição política, ou guerreira, quando a guerra é a política desenvolvida por outros meios. E já não diz respeito à filosofia, mas à propaganda ideológica.
} 
-se, como Annas e Barnes (2003, p. 41, 45). não deixam de também notar, que o que está posto nessas páginas, a título de informações, não o está como proposiçóes assertivas de crenças possuídas pelo cético. Ele distribui variaçóes as mais detalhadas, porque sabe que os dogmáticos as reconhecem bem. Mas, este é o ponto, ao fazê-lo, ele não só partilha com os dogmáticos da percepção da veracidade dessas informaçôes que são dados da experiência, como, de quebra, apontam para um estado de coisas comum, que não é posto para ser demonstrado por argumentação, senáo que pressuposto como efetivo e exposto como incontornável, no próprio ato de distribuir as informaçóes com as quais ele chegará a seu argumento principal, o da impossibilidade de decidir-se sobre um conflito de aparências que leva à suspensão do juízo.

Ao mesmo tempo em que reforçam a impossibilidade de tomar um ou outro lado da percepção como o único verdadeiro (a equipolência que força a suspensão do juízo), essas informações compóem um quadro cujos traços são tấo filosoficamente relevantes quanto o propósito para o qual ele foi pintado: "No caso dos modos nos quais os animais são produzidos, uns são engendrados sem cópula e alguns como resultado do intercurso." (SEXTO EMPÍRICO, 2000, p. 13s, 1993, p. 66). E a minudência com que se esforça por vincar a multiplicidade continua: "Entre os engendrados por cópula uns são produzidos por fogo, como as pequenas criaturas que aparecem na estufa, outros da água corrompida (estagnada), como mosquitos, alguns do vinagre, como os pernilongos, outros da terra." (SEXTO EMPÍRICO, 2000, p. 14, 66). E entre os engendrados a partir de uma união sexual: "Uns, como a maioria, de pais das mesmas espécies; e outros, como os mulos, de espécie distinta" (SEXTO EMPÍRICO, 2000, p. 14, 66) - o que leva, explicitamente, à seguinte conclusão: "É muito provável, portanto, que as dissimilaridades nos modos pelos quais eles são engendrados conduzem a largas diferenças nos modos pelos quais são afetados, trazendo como consequência o incompatível, o discordante, e o conflito dos contraditórios." (SEXTO EMPÍRICO, 2000, p. 14, 67). Isso desobriga o cético a tomar partido. E, implicitamente, a esta outra: o estado natural das coisas que nos aparecem tem um único traço identitário, de raiz comum, o de serem intrinsecamente diversos. Assim, seguir os costumes de acordo com a natureza, atitude a um só tempo cética e conservadora, ressurge a partir daqui sob uma feição completamente nova: seguir a natureza é aceitar a multiplicidade dos costumes como um todo vibrante e multifacetado.

O gosto pelo detalhe micrológico com que essa dupla tese é trabalhada segue sucessivas demonstraçóes no texto de Sexto: as diferenças no órgão da vi- 
são (SEXTO EMPÍRICO, 2000, p. 14, 67); as diferenças nos órgãos dos demais sentidos (p. 15, 68), como o funcionamento da língua na gustação; e as diferenças de constituição ou de peculiaridades físicas (p. 16, 69) que fazem uma mesma coisa ser experimentada de forma diferente, de acordo com cada animal posto a fazer a experiência de prová-la. Entretanto, o mais impressionante no meio de toda essa multiplicação de diferenças sem termo está no finalzinho desse primeiro tropo, quando a própria multiplicidade daria azo à tese dogmática da superioridade dos seres humanos sobre os outros animais. Porque, se tudo é diferença, então os seres humanos seriam diferentes (superiores!) aos outros animais. Sexto mostra, entre o gracejo e a seriedade, não haver diferença alguma entre eles; melhor: mostra que aquilo que os dogmáticos apontam como a marca maior da diferença entre os seres humanos e os outros animais (a razão, o logos) não está ausente nos demais bichos. Fala, a esse respeito, das duas célebres formas de logos, referidos na antiguidade já por Platão (MANETTI, 2012, p. 83-95): o logos endiáthetos ou a fala interior, o pensamento (diánoia); e o logos prophorikós, a expressão do pensamento no discurso (léxis), e, com um grão de sal, demonstra que, mesmo quando em níveis diferentes, também certos animais possuem essa qualidade humana de ponderar (a fala interior) e de expressar sua perspectiva: o cáo sabe quando se trata de seu dono que chega e quando se trata de um possível ladrão que se aproxima, e o modo de latir se diferencia segundo o caso, por exemplo.

Do ponto de vista cético, nessa não-diferença entre os demais bichos e o bicho humano, não havendo razão para destacar o homem do fluxo geral da animalidade, é interessante aceitar sem resistência sua inscrição nesse fluxo e enfatizar a irremediável e incoercível condição de multiplicidade e diferença a que ele está atado. Ora, nesse ponto também deve ser posto o problema central da diversidade dos costumes e da escolha moral dos valores: a efetividade da diferença física se desdobraria na realidade da diversidade cultural (poética <os modos de fazer $>$, ética <os modos de agir $>$ e nomotética < os modos de valorar, de legislar $>$ ). Aqui, portanto, a altura em que encontramos a possibilidade de examinar mais de perto o caráter dito conservador do ceticismo.

"Conservar os costumes" seria um imperativo a ser entendido sob duas perspectivas, a perspectiva particular do cético enquanto um ser humano comum, como todos os outros, situado em uma determinada cultura e época, que, ao sugerir fidelidade às formas de vida arraigadas, fala por si, sem intuito de fazer de sua escolha um imperativo a implicar a adesão de outrem. Isso segundo a compreensão "histórica" do ceticismo. Mas há a perspectiva filosó- 
fica, esta, do ceticismo: os costumes, como contrapartida e continuidade (por outros meios) da natureza, sáo justamente aquilo que se dá no movimento da diversidade: mudá-lo não é uma exigência a ser feita de fora para dentro; é a partir de dentro, "como se" naturalmente, que os costumes mudam (ou náo mudam), queira ou não o cético em particular (e, por isso mesmo, com mais razão, ele se deixa de boa vontade levar pelas formas estabelecidas de vida).

A prova, porém, de que é incoercível a mudança dos costumes está, justamente, nas muitas instituições criadas para mantê-los sempre iguais. Houvesse estabilidade natural e não haveria coerção institucional contra a mudança. Houvesse estabilidade natural e não haveria diferença entre a nossa cultura e as outras culturas. Antinatural, nesse sentido, não é que um povo ou um grupo de pessoas aja de formas diferentes da nossa, mas nós tentarmos impor a eles o nosso próprio caminho de viver e perceber o mundo e a vida. A diferença, supondo a diversidade e a multiplicidade, é ontologicamente primeira em relação à identidade, assim como a natureza (physis) é primeira em relação à cultura (póiesis, héxis, ethos, nomos) e, por isso, podemos dizer com certa tranquilidade, contra a filosofia tradicional: buscar a identidade da diferença é, na verdade, inventar essa identidade, de cada vez, de acordo com os interesses extrafilosóficos dominantes.

Ao passarmos ao exame do décimo tropo, estaremos, assim, ao mesmo tempo reencontrando o chão a partir do qual surgem as conflitantes proposiçôes filosóficas (elementos de cultura); reencontrando o problema fundamental da filosofia (o conflito de interesses, de projetos de mundo), mas, desta feita, sabendo, antes de qualquer solução oferecida, existir como efetiva uma unidade específica (inapreensível como unidade, porque cada vez que escolhemos uma feição para lhe dar concretude, por via de uma representação, de um conceito, ou de uma imagem, surge a oportunidade de lhe dar ainda outra feição, e ela não é nem essa nem aquela feição, mas a diferença entre ambas, e ainda entre uma provável terceira ou quarta), que, pelo fato mesmo de ser inapreensível, porque indeterminável, permite a multiplicidade de possíveis soluçóes, e que é a tentativa de impedir (mediante a determinação desse indeterminável), essa multiplicidade, de forçar o devir ao ser (ser este sempre entendido unilateralmente) que gera os conflitos, tanto na ordem da história quanto nos discursos filosóficos.

Em outras palavras, porque não existe como um dado (como é fácil observar, quando atamos as coisas sensíveis aos sentidos que as sentem, e liberamos estes de serem os guardiōes da certeza científica; quando, portanto, o 
liberamos da tarefa epistemológica e o deixamos simplesmente ver, confundir-se, embaraçar-se, fazer a experiência do mundo circundante, no seu turbilhão de verossimilhanças e enganos); porque, dissemos, não existe como um dado a unidade identitária enquanto princípio que assegurasse, para além das aparências, a realidade efetiva de todas as coisas postas, porquanto postas, a efetividade só pode ser, do ponto de vista ontológico, a própria multiplicidade; e o princípio dessa multiplicidade, a diferença como fundamento da universalidade e da particularidade, seria o conjunto das relaçóes tecidas e passíveis de serem tecidas entre as múltiplas aparências dadas.

Essa "diferença", que não é uma coisa, é, enquanto conjunto de relaçóes, o que poderíamos designar de psique como princípio das produçóes naturais ${ }^{12}$ (com seu lado passivo, pathetikós, e ativo, poiétikós) e das produçóes culturais (também elas com seu lado ativo, a imaginaçáo criadora, o trabalho, a produção de valores; e seu lado passivo, os costumes arraigados, a persuasão, o ethos, a héxis, o nomos). Por ora, pode-se dizer, psique trata-se apenas de um nome, e é claramente preciso ainda elevá-la a tema explícito de nosso discurso. Mas, antes, ainda é possível antevê-la, de novo, no modo como Sexto dá conta do material do último dos dez tropos, sobre estilos de vida, leis, os costumes, os mitos e as opinióes dogmáticas. Para ele, que considera esse material (etnológico) pelo lado da passividade (os costumes e os valores já assentados), diz-se "ético" daquilo que "depende de persuasão e costumes e leis e crenças no mito e nas suposições dogmáticas.” (SEXTO EMPÍRICO, 2000, p. 37). Seria porventura a persuasão que garante a sensação de realidade efetiva a respeito das coisas que, no fundo, têm sua realidade dependente pura e simplesmente de uma escolha, presumivelmente arbitrária. E é sob a pressuposição de que assim seja que Sexto examina seus minuciosos exemplos. Para nós, contudo, é ali onde uma escolha aqui (feita como a verdadeira escolha, porquanto eventual escolha do verdadeiro) não consegue destruir uma outra escolha possível feita acolá e também vivida na persuasão de que é a verdadeira escolha do verdadeiro, é ali que vemos escapar, do ato de dizer o verdadeiro, a diferença que fica por baixo das determinaçóes, como mais verdadeira que as escolhas diferentes tomadas como tais, como separação e eleição de um dos elementos separados.

Opondo costumes a costumes, ele escreve, por exemplo: "Os etíopes tatuam suas crianças, enquanto nós não” (SEXTO EMPÍRICO, 2000, p. 38 ), e, entre a certeza de que o certo é tatuar e a certeza de que o certo é não tatuar recém-nascidos, o cético suspende o juízo. $\mathrm{O}$ que vemos por baixo do

${ }^{12} \operatorname{Naddaf}$ (2005, p. 18): "Psique tem mais de um direito de ser chamada physis" ("força produtiva"). 
juízo suspenso? A efetividade de haver dois possíveis e diferentes modos de agir. Opondo costumes a leis: "Na Pérsia atos homossexuais são corriqueiros, enquanto em Roma eles são proibidos por lei." (SEXTO EMPÍRICO, 2000, p. 38). De novo, para o cético, a ocasião de suspender o juízo e, de novo, para nós, a chance de ver o que jaz nisso: a lei, que tem poder de fazer efetiva uma realidade possível, aqui, não desfaz a efetividade de seu contrário, alhures, e no fundo resta que o verdadeiramente efetivo não é a lei, nem a prática a ela contrária, mas a eventualidade de haver, no mundo, as duas. Opondo costumes a persuasão: "Muitos homens fazem sexo com sua mulher privadamente, enquanto Crates o fazia com Hipárquia em público.” (SEXTO EMPÍRICO, 2000, p. 39). Crates teria sido um dos filósofos cínicos, e a marca maior do cinismo era a denúncia do caráter fabricado dos costumes; daí a ousadia de romper com eles e fazer, sem pudor, aquilo que lhes é justamente afrontoso. Entre uma convenção e uma ruptura da convenção, o cético suspende o juízo, e nós espiamos por baixo do suspenso para ver o efetivo: estar de acordo e estar em desacordo são atitudes multiplamente possíveis. Opondo costumes a mitos: "Os mitos diziam que Cronos devoravam seus próprios filhos, enquanto entre nós é costume cuidarmos dos nossos." (SEXTO EMPÍRICO, 2000, p. 39). Os mitos dizem; os costumes fazem. Entre dizer e fazer, o cético prefere suspender o juízo, e de novo nós olhamos por baixo do que fora suspenso: vemos a efetividade do dizer e do fazer como coisas distintas igualmente possíveis. Costumes são opostos, agora, a suposiçóes dogmáticas: "Conosco ocorre de pedir coisas boas aos deuses, enquanto Epicuro diz que a divindade não presta atenção em nós.” (SEXTO EMPÍRICO, 2000, p. 39). Uns esperam pelos deuses, outros se desesperam. Quais têm razão? O cético suspende o juízo. E nós, o que vemos? A efetividade de haver crentes e descrentes como um fato, e também o cético a "ficar na sua" e não entrar nessa discussão. Olhado do ponto de vista do globo terrestre como um todo, o mundo seria um lugar rico de tolerância.

Mas as contraposiçôes continuam. Agora Sexto opóe a persuasão à lei: "Embora haja uma lei que diz que um homem livre de boa família não deve ser espancado, os lutadores greco-romanos se batem uns contra outros porque isto é uma coisa dada como certa na sua forma de vida." (SEXTO EMPÍRICO, 2000, p. 39). O que ali é proibido por lei, acolá é concebido como honrado. Entre a honra de não ser espancado e a honra de poder bater, qual a escolha do cético? Ele não entra na discussão, suspende o juízo e nos deixa ver a efetividade de haver honra em lugares inauditos, e das mais diferentes possíveis. Opóe, então, crença nos mitos a persuasão: "Os mitos dizem que Hércules fora es- 
cravo e cardou lâ, não obstante Hércules estava convencido de ser um nobre.” (SEXTO EMPÍRICO, 2000, p. 39). Os mitos dizem de coisas absurdas que temos de passar na vida, e nós sabemos, independentemente disso, do valor que temos em nosso fórum íntimo. Quem tem razão, a vida que maltrata ou nós que nos sabemos melhores do que aquilo que a vida, às vezes, nos dá a viver? O cético suspende o juízo e, por baixo o que vemos é isso: a efetividade de a vida maltratar as pessoas e de as pessoas não perderem sua dignidade, apesar dos maus tratos da vida. Opóe, ainda, persuasão a suposição dogmática: "Atletas perseguem a glória como um bem [...], enquanto vários filósofos sustentam a crença de que a glória é uma coisa má." (SEXTO EMPÍRICO, 2000, p. 3940). O que, portanto, seria o melhor: ser famoso ou viver uma vida obscura? O cético suspende o juízo e nós, de relance, vemos a efetividade de haver vidas vividas no anonimato como vividas ante holofotes como igualmente possíveis.

Opõe lei a crença em mitos: "Os poetas representam os deuses cometendo adultério e praticando atos homossexuais, enquanto conosco a lei proíbe essas coisas." (SEXTO EMPÍRICO, 2000, p. 40). Agir como os deuses míticos ou seguir a lei da cidade? Suspenda-se o juízo, e nós vemos o que há por baixo: a ficção do poetas e a ficção dos legisladores como dados efetivos; ou, dito de outro modo, quando tudo é ficção, a realidade efetiva só pode ser concebida como a imaginaçáo criadora que dá a oportunidade de vir ao ser às ficçôes, seja como lei, seja como mito etc. ${ }^{13}$

Desse modo, na natureza como na cultura, a realidade efetiva não está nem em uma posição tomada por alguém em relação a um estado de coisas possível, nem em outra passível de ser igualmente tomada por outrem, em relação a outro estado de coisas oposto, mas na ausência completa de qualquer determinação prévia que assegure maior peso ontológico e axiológico a uma coisa que a outra, a uma ou a outra tomada de posição. É essa ausência o que vemos sob a suspensão do juízo exercida pelo cético. É essa ausência, afinal, o princípio de todas as coisas, na medida em que todas as coisas "a" ou "b" são igualmente efetivas aqui (e possíveis alhures), como efetivas alhures (e possíveis aqui), e isso não conduz à defesa de nenhum relativismo, no entanto, aponta o absoluto da situaçáo de multiplicidade.

Conforme se percebe, o pós-ceticismo atravessa o ceticismo por baixo e, fugindo do relativismo, assenta uma verdade: a de que a "diferença" é um princípio, a efetividade incontornável que garante a multiplicidade de visóes

${ }^{13}$ Sobre a relação entre lei e ficção, referindo-se a Kafka, cf. Lima (1993). 
e de visadas, mas a verdade pós-cética não é uma coisa a ser detida, e sim uma ausência potente, um nada divino, ${ }^{14}$ de imensa força. ${ }^{15}$ Eis, portanto, como, para dar conteúdo ao ceticismo, é possível contornar o relativismo e, ao mesmo tempo, não ser dogmático. Há uma verdade, afirmamos com o ceticismo pirrônico, entretanto, essa verdade não precisa, afirmamos contra o mesmo ceticismo, ser buscada infinitamente: ela se póe abaixo de nós antes de qualquer proposição, na imanência de nossa variada experiência de mundo, ao passo que cada proposiçáo, ao mesmo tempo em que apenas a toca sem nada dela apreender em definitivo, mostra por esse ato mesmo de não-apreensão a natureza íntima dessa verdade, a saber, a de ser a unidade inapreensível de uma multiplicidade de proposiçóes insuficientes à tarefa de fechar o pensamento num princípio que sustentaria sozinho uma forma única de organizar a vida na Terra.

Dogmatismo é tomar uma dessas proposições como sendo um princípio inultrapassável. Relativismo é dizer que uma proposição vale tanto quanto a outra, e ficar nisso. Ceticismo acadêmico é desesperar de enunciar algo. Ceticismo pirrônico é desesperar de afirmar algo, mesmo crendo ser possível vislumbrar em algum lugar a verdade. O pós-ceticismo se sustenta da afirmação de que há um único princípio e uma única verdade: a multiplicidade das proposiçóes de princípio, o pluralismo das formas de vida. Todavia, em que essa posição final se distingue do relativismo? Nisto, precisamente: o relativismo é a desistência de pensar o universal, enquanto o pós-ceticismo, deixando as disputas entre proposiçóes de princípios discordantes que orientam formas de vida distintas decidam-se na faina pragmática da política, assegura para o pensamento um lugar fora de todo pragmatismo, um campo onde não importa quem chegue, e de onde venha, na medida em que deseje pensar, e não simplesmente se fazer justificador de decisóes tomadas de antemão, sempre há

\footnotetext{
${ }^{14}$ Eric Voegelin o designaria como "fundamento divino não existente de existência." (VOEGELIN, 2010a, p. 137)

${ }^{15}$ Quem, dentre nós, melhor viu essa força foi Rubens Rodrigues Torres Filho, quando estudou a doutrina-da-ciência fichtiana como imaginação pura. Cf. Torres Filho (1975). Que o "nada" nos advenha concebido como não-existente, isso já é um resultado da vitória da oposição que lhe foi feita por milênios de representaçôes em que o "ser" (concebido como ente realíssimo) usurpou do "nada", à força de sua desqualificação, seu poder de invenção. O ser, o logos e mesmo a verdade (aletheia), quando ao "nada" se lhe restitui o poder todo seu, o de inventar, passam à compreensăo como de segunda categoria ontológica. O pseudo (o velado), anterior àquilo que o desvela (a verdade, a-letheia), quando traduzido por "falso", é traído de forma letal em seu próprio leito de silêncio pejado de significaçôes. (Ilação de fundo heideggeriano, foi, entretanto, em parte desenvolvida por Theodor Adorno (2009) e, em parte, por Cornelius Castoriadis (2007)).
} 
de encontrar o mesmo princípio: há o múltiplo; e impor o uno que desfaça a multiplicidade será sempre um ato de violência.

É nessa altura, quando caracterizamos o fundo de efetividade do real, a psique, como um "nada" poderoso, que nossa discordância ambígua com Oswaldo Porchat, traçada em surdina ao longo deste ensaio, torna-se mais lancinante, e tem porventura a chance de ser resolvida. Para ele, a visão comum do mundo vê o que está aí, posto, e se contenta com isso (sem fazer distinção entre o que está posto pela natureza e o que o está pela cultura). Sua filosofia começa com esse contentamento. Todavia, parece haver ao menos duas formas de aceitar já posto, e é a falta de clareza quanto a isso quem nos leva muito facilmente a identificar como um só procedimento a posição cética e a resignação conservadora. A primeira é dizer: o mundo é isso que se vê na superfície de suas coisas [a "base sólida" de que fala Porchat, (2007, p. 66)]; a segunda seria: tendo visto tudo quanto o mundo tem sido (posto), a verdade do que tem sido (posto) é que há um movimento (absolutamente fluido) de posiçóes (de atos de pôr), movimento pelo qual o que tem sido vem ao ser e no ser permanece até o tempo de sua contestação.

Nossa discordância com Porchat é ambígua, porque ele, que toma a parte pelo todo, quando afirma "O mundo [...] é presença imediata que torna ocioso, torna em verdade absurdo qualquer projeto de legitimaçáo outra que o discurso que a exprime" (PORCHAT, 2007, p. 56), toca todavia o que nos parece certo e verdadeiro, quando diz: "No Princípio o Verbo não era [...]. As filosofias são apenas produtos da prática teórica dos homens, fatos da vida comum" (PORCHAT, 2007, p. 57), e, adiante, à página 116, põe o corpo como limiar vivo entre natureza e cultura, como primeiro em relação às teorias filosóficas que, juntamente com o mundo, gostariam de desqualificá-lo por meras questôes de método. Mas a filosofia e todo o mundo "sólido" são "apenas produtos" - expressão de Porchat, da qual alteramos a ênfase. Com efeito, Porchat fala como quem acaba de tomar seu café da manhã (provavelmente feito por uma mulher). Nós ainda estamos deitados, acordados, decerto, mas em silêncio e de olhos fechados, sentindo a respiração do corpo e a pressão do plano sobre o qual deitamos, estamos nesse limiar entre o fim de um sono e o início da vigília, do despertar, que também pode ser chamado de "atualidade". 
O "não ser" do Verbo, esse silêncio absoluto, que está "no Princípio" e é efetivamente o Princípio, náo impediria, por amor à radicalidade, que nos emperrássemos na "Visão comum" do mundo, e seu caudal de preconceitos, assim como na visão filosófica de mundo e seu alforje de conceitos, e também na visão científica, com seu bornal de teorias, e na percepção religiosa do mundo, com suas certezas para lá de necessárias e inquestionáveis? Ou seja, quando a tarefa é enunciar o Princípio como ausência produtiva, vazio de enunciados, nada, porém sob a forma de produção (e não de produtos), não seria o caso colocar a visão comum ao lado da filosofia e dos outros tipos de manifestaçáo simbólica, como rebentos de um campo de trabalho de pensamento mais amplo? Suspender o juízo sobre ambas (e todas) e perceber, no fundo, a própria fábrica de produçáo do real, por meio da produção daqueles símbolos (o preconceito, o conceito, as teorias e as certezas, as crenças e as persuasôes) não nos abriria a uma universalidade mais radical, posta a evitar unilateralidades dogmáticas, mesmo quando vindas do senso comum?

A partir de nosso ponto (esse vazio indeterminado), não seria apenas o conflito das filosofias que se dissolveria, mas também o conflito entre filosofia, visão comum de mundo e todas as outras visóes. Contudo, esse ponto informulável das formas de pensamento e das formas de sociabilidade multiplamente elaboráveis, não seria um silêncio absoluto? Que o leitor faça esta experiência: antes de abrir os olhos pela manhã, ao despertar, que língua será a sua, que visão comum compartilha, em que mundo vai pôr os pés, que há de ser feito de seu dia, em que ano está, é "evoluído" ou ainda está nas cavernas, nas savanas? Que horas são? De olhos fechados e em silêncio (e ainda deitado), que diferença pode haver entre ele, o homem pré-histórico e o besouro de Kafka?

Antes, porém, de abrir os olhos e abraçar, com esse corpo que é tudo o que se tem, o mundo tal como ele é, com seu quinhão de esplendor e de miséria, que sejam considerados alguns pressupostos. O primeiro: que esse corpo que abraça o mundo é táo vivo quanto o próprio mundo (JONAS, 2004). O segundo: que náo há diferença essencial entre o homem da savana e o homem da cidade: na "hora do sufoco", o verniz que a civilizaçáo nos emprestou se torna subitamente opaco, e somos tão selvagens ou mais do que o mais cruel dos selvagens (na hipótese, claro, de que os selvagens sejam "cruéis", porque também isso não passa de etnocentrismo) (CANETTI, 2013). O terceiro: que há uma dialética da passagem entre a natureza inorgânica e a orgânica, tanto quanto entre ambas e o ser social (LUKÁCS, 2012). Quarto: que não há diferença, a não ser de grau, entre o conhecimento mítico e o conhecimento 
científico (CASSIRER, 2010). Quinto: que a referência a um ser físico e a um ser social implica a necessidade de uma teoria geral do ser capaz de esclarecer a natureza do princípio pelo qual se dão esses dois "seres" (VOEGELIN, 2010b). E é somente quando explicitamos esse quinto pressuposto que podemos entender que a primeira obra da natureza é o tempo (cósmico), assim como, antes mesmo da linguagem, do rito, do mito, a primeira obra da cultura é também o tempo (humano), e o princípio produtor do tempo, a que nos arriscamos chamar de "nada", de "diferença", de "psique" - entendida como um crisol de relaçôes - seria aquilo que dois autores táo distantes quanto Voegelin e Deleuze (ao lado de Guattari) chamariam de "Isso" (VOEGELIN, 2010b, p. 38; DELEUZE; GUATTARI, 2012.), comum quer à natureza, quer à história, silêncio absoluto como parte inicial de uma frase musical de que é feito o próprio pensamento, campo transcendental; ou grau zero da significação, o sem-sentido somente de onde é possível esperar ver brotar o sentido.

É do fundo desse "campo" como "Isso" (psique: unidade da continuidade e descontinuidade entre physis e póiesis) (CASTRO, 2012; NADDAF, 2005; DESCAT, 1986), com efeito, que viria avançando, como uma canção, todo o universo, e, dentro desse universo, os seres animados, e, dentre os seres animados, os seres humanos, e, pelos seres humanos, a linguagem, os ritos, os mitos, as religióes, os comportamentos, as artes, as ciências, as tecnologias, e, no meio de tudo "isso", a tentativa agônica (de muitas vozes) de organizar (na grande política do discurso, do logos) uma forma de vida que faça minimamente sentido, tal como ocorre entre os kisêdjê (SEEGER, 2015), onde o canto não é um produto cultural, mas o meio de produção da própria cultura como um todo social.

O conflito entre as filosofias, como entre as religióes, torna-se assim problema a ser eliminado somente quando se pensa que, entre dois grandes caminhos, há que se escolher um, na ânsia de que o escolhido traga consigo o acesso à verdade como aquilo que se impóe a todos: se um encontra a verdade, pode arrastar o outro consigo. $\mathrm{O}$ que não se percebe, com essa representação de "grandes caminhos", é que, quando se tem acesso à verdade (ao pseudo, sua fonte), tal como aqui aludida, a grandeza de um caminho só existe depois que se o escolhe, e que haveria menos conflito se se deixasse de evitar o conflito (nascido pela imposição de uma escolha determinável) e se multiplicassem os caminhos de escolha. 
Ou seja, o grande problema da filosofia - dizer o que seja a verdade como princípio sustentador de uma forma de vida possível - não é que haja conflitos entre suas correntes, mas que haja correntes insuficientes.

Se a "verdade" for, como supusemos acima, uma espécie de fonte inesgotável, logo, cada um tem o direito de propor sua forma de tocar e de explicitar essa verdade, como, diante de um poema, cada leitura é sempre uma proposta de interpretação, jamais a doação do sentido último do poema. Seria preciso, então, que mais gente se prontificasse a fazer mais e mais filosofias, até o limite em que todos e cada um pudessem sentar-se na mesma mesa, e ouvir e falar de sua experiência com a verdade, percurso do pseudo ao logos, da experiência antepredicativa à fala que ordena essa experiência; seria preciso não menos, porém mais e mais religióes, até o limite do sacerdócio universal, onde cada um fosse o pastor e o rebanho de si mesmo, e no corpo próprio experimentasse as delícias da transcendência mística; até o dia em que cada indivíduo, em paz consigo mesmo e com ao menos um de seus mundos possíveis, pudesse dialogar com outro, no reconhecimento da mais radical diferença entre suas crenças e seus pensamentos.

O problema, pois, não está em haver muitas filosofias, muitas religiões, muitas teorias científicas, muitas opiniōes. Há-os pouco. O problema está em ainda náo termos construído condiçóes sociais concretas (nem consequentes formas de pensamento) para haver, sem algazarra, mais gente produzindo filosofia, produzindo modos de exercer uma relação com o transcendente, modos de olhar e viver com zelo, e publicamente, o mundo de múltiplas maneiras.

ANDRADE, A. Skepticism and truth: essay on the radical universality of a post-skeptical thought. Trans/form/ação, Marília, v. 41, n. 3, p. 9-38, Jul./Set., 2018.

ABstract: Based on a study of the tropes of Aenesidemus discussed by Sextus Empiricus in his Pyrrhoniae Hypotyposes, we propose a reading which leads us to the need to postulate for contemporary thought a new universality that is radical and insurmountable. By this means, the philosophical content and scope of skepticism can be understood in the sense of an encounter - finally - with the much sought after notion of truth as that which can not be possessed, or whose announced possession is always the revelation of a one-sidedness. In addition, a place of non-relativistic thought can be secured against dogmatic intolerance and against dissatisfaction with the conflicts of philosophy.

KeYwords: Epoché. Psyche. Physis. Poiesis. Skepticism. Truth. Radical universality. 


\section{REFERÊNCIAS}

ADORNO, T. Dialética negativa. Tradução de M. A. Casanova. Rio de Janeiro: Zahar, 2009.

ANDRADE, A. C. Fragmento como forma: a filosofia na experiência da modernidade. São Paulo: Opção, 2016.

ANNAS, J.; BARNES, J. The modes of scepticism: ancient texts and modern interpretations. Cambridge: Cambridge University Press, 2003.

BROCHARD, V. Os céticos gregos. Tradução de Jaimir Conte. São Paulo: Odysseus, 2009.

CANETTI, E. Massa e poder. Tradução de S. Tellarolli. São Paulo: Companhia das Letras, 2013.

CASSIRER, E. A filosofia das formas simbólicas. São Paulo: Martins Fontes, 2010. V. 1-3.

CASTORIADIS, C. Sujeito e verdade no mundo social histórico. Tradução de E. Aguiar. Rio de Janeiro: Civilização Brasileira, 2007.

CASTRO, S. de. A teoria aristotélica da substância. Rio de Janeiro: Contraponto, 2008.

DELEUZE, G.; GUATARRI, F. O anti-Édipo: capitalismo e esquizofrenia. Tradução de L. B. L. Orlandi. São Paulo: Ed. 34, 2012.

DESCAT, R. L'acte et l'éffort: une idéologie du travail em Grèce ancienne. Paris: Centre de Recherches d'Histoire Ancienne, 1986.

FIORI, E. M. O fio condutor de um pensamento itinerante. In: Metafisica e história: textos escolhidos, v. 1. Porto Alegre, L\&PM, 2014.

HEGEL, G. W. F. Fenomenologia do espirito. Tradução de P. Meneses et al. Petrópolis: Vozes, 2011.

HUME, D. O cético. In: . Ensaios morais, politicos e literários. Traduçáo de A. Sérgio et al. Sáo Paulo: Nova Cultural, 1992.

JONAS, H. O princípio vida. Tradução de C. A. Pereira. Petrópolis: Vozes, 2004.

LIMA, L. C. Limites da voz. Montaigne, Schlegel, Kafka. Rio de Janeiro: Rocco, 1993.

LUKÁCS, G. Prolegômenos a uma ontologia do ser social. São Paulo: Boitempo, 2012.

MANETTI, G. Lógos endiáthetos e lógos prophorikós nel dibattito antico sulla razionalità animale. Traduzione e significato di una coppia emblemática. I Quaderni del Ramo d'Oro, online, n. 5, p. 83-95, 2012. Disponível em: <http://www.qro.unisi.it/ frontend/node/140>. Acesso em: 05 abr. 2015.

NADDAF, G. The greek concept of nature. Nova Iorque: State University of New York, 2005. PORCHAT PEREIRA, O. Rumo ao ceticismo. São Paulo: UNESP, 2007. 
SEEGER, A. Por que cantam os kisêdjê. Tradução de G. Werlang. São Paulo: Cosac Naify, 2015.

SEXTO EMPÍRICO. Opera. V. I. Pyrroneion Ypotypozeon. Edição do texto grego de Hermannus Mutschmann. Lipsiae: Typis B. G. Teubneri, 1912. p. 61. Disponível em: https:// archive.org/stream/sextiempiriciope01sext\#page/n9/mode/2up. Acesso em: 05 abr. 2015

SEXTO EMPÍRICO. Esbozos pirrónicos. Tradução de A. G. Cao e T. M. Diego. Madrid: Gredos, 1993.

SEXTO EMPÍRICO. Outlines of scepticism. Editado por J. Annas e J. Barnes. Cambridge: Cambridge University Press, 2000.

TORRES FILHO, R. R. O espírito e a letra: a crítica da imaginação pura, em Fichte. São Paulo: Ática, 1975.

VAZ, H. C. de L. Escritos de filosofia II: ética e cultura. São Paulo: Loyola, 1988.

VOEGELIN, E. Ordem e história: era ecumênica. Tradução de E. Bini. São Paulo: Loyola, 2010a. V. 4.

VOEGELIN, E. Ordem e história : em busca da ordem. Tradução de L. Pudenci. São Paulo: Loyola, 2010b. V. 5.

VOGT, K. Ancient Skepticism. In: ZALTA, E. N. (Ed.). The Stanford Encyclopedia of Philosophy. Winter Edition, 2014. Disponível em: <http://plato.stanford.edu/archives/ win2014/entries/skepticism-ancient/>. Acesso em: 05 abr. 2015

WOODRUFF, P. The pyrrhonian modes. In: BETT, R. The Cambridge Companion of Ancient Scepticism. Cambridge: Cambridge University Press, 2010. p. 208-231.

Recebido: 2016-02-20

Aceito: 2017-06-05 
ANDRADE, A. 